\title{
The Impact of Luther and the Reformation in the Portuguese Seaborne Empire: Asia and Brazil, I $520-1580$
}

\author{
by JOSÉ PEDRO PAIVA \\ University of Coimbra \\ E-mail: lejpaiva@fl.uc.pt
}

\begin{abstract}
This article assesses how Lutheran and other Reformation doctrines spread and were countered in the Portuguese seaborne empire. Portugal's inquisitorial and episcopal repression of 'Lutherans' was extended to Brazil and Asia, where it was supported by the Society of Jesus. The Portuguese empire's transcontinental connections favoured the emergence of interconnected histories, facilitating the circulation of books, engravings and beliefs and thus provided nonPortuguese people with links to the reformed world that spread amongst and disturbed the Portuguese living in India and Portuguese America. By opening up routes the Portuguese, paradoxically, functioned as vectors for other ways of interpreting Christianity.
\end{abstract}

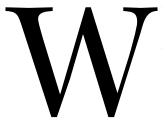
hen, in $15^{13}$, on a 'solitary and invisible' journey, Luther found his 'inner peace', the Portuguese in Asia, headed by Vasco da Gama, had already reached India (1498), conquered Malacca

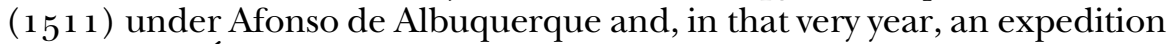
led by Jorge Álvares had arrived in China. ${ }^{1}$ At the same time Brazil was an

This article was supported by the project 'ReligionAJE: Religion, Ecclesiastical Administration and Justice in the Portuguese Seaborne Empire (1514-1750)', PTDC/HAR-HIS/28719/2017, which is sponsored by the Portuguese Foundation for Science and Technology, FCT, H202o. My thanks to Sheena Caldwell for work on the translation of both the text and the quoted material.

${ }^{1}$ Lucien Febvre, Martinho Lutero: um destino, Lisbon 1976, 53. Others have presented Luther in more contradictory terms. Lyndal Roper, for example, writes that 'I am 
integral part of the various dispersed territories which made up the Portuguese overseas empire. As the Portuguese empire was expanding and presenting the world with the first signs of globalisation, Luther, who from ${ }^{1} 5^{13}$ to $15^{16}$ lived in Erfurt as an Augustinian friar, 'became Lutheran'. He did so by finding a path to salvation in the doctrine of justification by faith ('the righteous are saved by faith'), by reading the works of St Augustine, which revealed to him the absolute power of the grace of God. ${ }^{2}$ However, recent studies tend no longer to dramatise the solitary 'Tower experience'. One of the latest and most thorough biographies of Luther emphasises that his 'defining religious experience' was the 'discovery of the Gospel', which showed him the way to the 'good news of justification by faith'. This 'discovery' provided him with 'comfort' and made it possible for him to assuage the triad of 'sin, guilt and damnation' embedded in the Christianity of his time which, for him, implied 'intolerable suffering'. ${ }^{3}$ To paraphrase Adriano Prosperi, it may be said that while others 'were discovering uncharted worlds and seas, Luther discovered a hitherto unknown religious world' in an 'era ruled by faith', as Goethe had suggested in the nineteenth century. 4

Given the emergence of this new way of interpreting Christianity, at a time when the faith was becoming truly universal as it expanded into Asia and America, 5 this study will assess how Lutheran doctrines and other elements of the Reformation circulated, were subject to surveillance and were curbed within the Portuguese empire, focusing on Asia and Brazil during the period from $15^{20}$ to $15^{80}$.

\section{Warning signs and repression in Portugal}

Since the $15^{20}$ there had been concern in Portugal about the circulation of Lutheran ideas and the threat represented by the spread of this new

interested in Luther's contradictions': Martin Luther: renegade and prophet, New York 2017 , p. xxvii.

${ }^{2}$ Pierre Chaunu, Le Temps des reformes: la crise de la chrétienté: l'eclatement, I250-1550, Paris $1975,387-99$.

3 Adriano Prosperi, Lutero: gli anni della fede e della libertà, Milan $2017,83-8$. Another excellent biography of Luther emphasises that 'reading the Bible became central to his existence'. It explains, however, that 'Luther's love of Scripture was [not] novel and revolutionary. The Waldensians of the twelfth century had placed the reading of the Bible at the heart of their devotional practices': Heinz Schilling, Martin Luther: rebel in an age of upheaval, Oxford $2017,75^{-6 .}$

4 Goethe's perspective was revived recently in Schilling, Martin Luther, 1, $54^{2}$.

5 One English historian has argued that even if it were not the first world religion, Roman Catholicism in the sixteenth century was 'the globe's most kinetic religion': Simon Ditchfield, 'Catholic reformation and renewal', in Peter Marshall (ed.), The Oxford illustrated history of the Reformation, Oxford $2015,152$. 
THE REFORMATION AND THE PORTUGUESE SEABORNE EMPIRE 285 interpretation of Christianity in various parts of Europe. The earliest evidence of these fears dates back to 29 August 1520 when Miguel da Silva, the future bishop of Viseu, but currently ambassador to Rome, wrote to Manuel I (r. 1495-1521) to inform him that the pope had issued the bull Exsurge domine against Luther which he had simply 'laughed at'. In December of that year Luther would burn that document in Wittenberg. Da Silva added, voicing current fears, that 'this is cause for anxiety, because everyone is now asking for the Council and for reform' ${ }^{6}$ Shortly afterwards the king expressed his concerns to the Emperor Charles v.7

During this decade, however, there was no strict vigilance or repression, despite measures introduced by Rome to prevent the circulation of books containing the new doctrines. Hence, in his Ropica Pnefma (1532) the famous Portuguese historian and humanist João de Barros (1496-1570) would refer to inhabitants of Lisbon who 'spoke so freely [about Lutheran ideas], as if they were in Germany with Luther', 8 and the court poet and chronicler Garcia de Resende would write in 1530 that

\author{
With heresies and cunning \\ We see false Luther working \\ In Germany converting many \\ A clever feat as any. \\ Against our faith he preaches \\ Against the pope blasphemes ... \\ And, most pitiful of all, \\ We see this poison spread withal \\ To other lands \\ Bringing now the plague of war \\ When we are slow to find a cure.9
}

6 'he esta huma causa que tyra o somno porque todo aquelle povo pede concílio e reformação': Corpo diplomático Portuguez contendo os actos e relações políticas e diplomáticas de Portugal com as diversas potencias do mundo desde o século XVI até aos nossos dias, Lisbon 1862-1959, ii. 33; Paulo Drumond Braga, A Inquisição nos Açores, Ponta Delgada 1997, 270.

7 Paulo Drumond Braga, 'Carta de D. Manuel I a Carlos v sobre a rebelião de Lutero (1520)', Itinerarium xxxix (1993), 33-43.

8 'falam tão solto como se estevessem em Alemanha nas xiras de Lutero': João de Barros, 'Ropica Pnefma', in Ropica Pnefma: reprodução fac-similada da edição de 1532 , ed. I. S. Révah, Lisbon 1983, ii. 5 .

9 'Com heresias e manha/vimos ho falso Luterio/Converter em Alemanha/Tanta gente que he façanha/Contra nossa fee pregando/E do papa brasphemando ... / Ho que mais deve doer/He que veemos extender/Este veneno a mais terras/E com pestiferas guerras/Tarda remedio poer': Garcia de Resende, Miscellanea e variedades de historias: costumes, casos e cousas que em seu tempo aconteceram, Coimbra 1917, 83; Braga, A Inquisição, 271. 
News of the arrest, in Lisbon, of the first Lutherans only appeared in 1530. They were Germans and the brief report appears in the correspondence of the Castilian ambassador in Portugal. ${ }^{10}$ In October 1536 the trial of the Flemish weaver Robert Hix opened, with the entire proceedings heard in the Lisbon ecclesiastical court by Archbishop Afonso, son of Manuel I and brother of John III (r. 1521-57). The defendant, who had been accused of Lutheranism and of attempting to convert employees in his workshop, abjured in a public ceremony held at the episcopal tribunal in March $1537 \cdot{ }^{11}$

After the Inquisition was established in May 1536, a more intense and systematic wave of repression was launched against Lutheranism, Calvinism and other reformist movements usually defined in ambiguous terms by the inquisitors. On 22 December 1536 , in Evora, the first Inquisitor General Diogo da Silva heard the preliminary accusations against Pedro Corte Real, a nobleman from the royal household, who was convicted in 1542 for having claimed that Luther spoke the truth. Later, the arrest of several teachers from the College of the Arts in Coimbra, who were imprisoned in August 1550, and the case of William Gardiner, the first defendant accused of Lutheranism to receive the death penalty in $155^{2}$, had a significant impact on Portuguese society. ${ }^{12}$

From the mid-1 $55^{\text {os }}$ onwards repression increased. Most of the defendants were tried by the Lisbon Inquisition, in particular foreigners (French, Dutch, English, Germans, Irish and even some Spaniards and Italians). ${ }^{13}$ The number of convictions peaked in $15^{61}$ with twenty-eight trials for 'Lutheranism'. ${ }^{14}$ The following year, the Augustinian friar Valentim da Luz was convicted and handed over to the secular arm, the first and one of the very few Portugueses subjects to receive such a harsh sentence. ${ }^{15}$

If no further trials ensued, in particular any involving Portuguese subjects, this was because the Inquisition had become more vigilant. ${ }^{16}$ However, as has recently been clearly established, this did not mean that

${ }^{10}$ Aude Viaud, Correspondance d'un ambassadeur castillan au Portugal dans les anneés I530: Lope Hurtado de Mendonza, Paris 2001, document 75 .

${ }_{11}$ Isaías da Rosa Pereira, 'Um processo inquisitorial antes de haver Inquisiçāo', Anais da Academia Portuguesa de História, 2nd ser. xxvii (1982), 193-277.

${ }^{12}$ Giuseppe Marcocci and José Pedro Paiva, História da Inquisição Portuguesa (1536I $82 \mathrm{I}$ ), Lisbon $2013,77-80$.

13 Isabel M. R. Mendes Drumond Braga, Os estrangeiros e a Inquisição Portuguesa (séculos XVI-XVII), Lisbon 2002, esp. pp. $219-62$.

${ }^{14}$ Daniel Giebels, 'A Inquisição de Lisboa: no epicentro da dinâmica inquisitorial (1537-1579)', unpubl. PhD diss. Coimbra 2016, 227.

${ }_{15}$ Arquivo Nacional Torre do Tombo, Lisbon (hereinafter cited as ANTT), Inquisição de Lisboa, processo 8352; José Sebastião da Silva Dias, O erasmismo e a Inquisiçāo em Portugal: o processo de Fr. Valentim da Luz, Coimbra 1975.

16 Marcocci and Paiva, História, $84^{-} 5$. 
THE REFORMATION AND THE PORTUGUESE SEABORNE EMPIRE 287 Protestant ideas and attitudes had not been circulating and discussed in various parts of Portugal by people from various sociocultural backgrounds, including clerics. ${ }^{17}$ In fact, approximately 25 per cent of those convicted of Lutheranism by the Lisbon Inquisition were Portuguese. It was the vigilance and repression carried out by the Inquisition that prevented the ideas of Martin Luther and other reformers from spreading further and taking root in Portugal.

\section{What happened in Asia?}

What was happening in Asia while in Portugal the Inquisition was pursuing its repressive policy?

Although there is a great deal of correspondence dating from the period $1523-46$ written by various agents, particularly Jesuits, working in the East, it contains no references to Luther or Protestantism. The main concerns were Muslims and Hindus. The only exception was the news sent to John III of the death sentence imposed by the episcopal justice system on a Portuguese New Christian for expressing 'worse heresies than those uttered by Luther, Zwingli and Oecolampadius'. ${ }^{18}$ This indicates that at least the names of some of the key figures in Protestantism were already known and feared in Goa in 1539 in the context of the repression triggered by Bishop Juan de Albuquerque (1537-53). According to some correspondents it was then that a treaty, signed by Ragunatha Nayak of Tanjore and the Danes who had settled in Tranquebar, permitted the latter to freely practise their faith. ${ }^{19}$ The evidence suggests, then, that as early as 1539 the ideas and beliefs of those at the forefront of a new way of understanding Christianity and the organisation of the Church could, to varying degrees, result in conversions amongst the inhabitants of these areas, but nothing more is known about this due to the lack of historical sources.

In October 1545 the attention directed by Juan de Albuquerque to heresy, at a time when the Inquisition was already functioning in Portugal but the Goa Tribunal had not yet been founded, was noted by the Italian Jesuit Antonio Criminali. Writing to Ignatius of Loyola from Goa, he stated that open 'heretics' were 'severely punished by the bishop, but those who were not open did as they pleased'. His letter does

17 Giuseppe Marcocci, 'Una tierra sin herejía? La reforma en Portugal', in Michel Boeglin, Ignasi Terricabras and David Kahn (eds), Reforma y disidencia religiosa: la recepción de las doctrinas reformadas en la Península Ibérica en el siglo XVI, Madrid 2018, $213-26$.

18 ANTT, Corpo Cronológico, parte 1, m. 66, doc. 47, fos $15^{-16}$; Ana Cannas da Cunha, A Inquisição no Estado da Índia: origens (I 539-1 560), Lisbon 1995, 252-4.

${ }^{19}$ Daniel Jeyaraj, 'Luther in Asia: India', in Alberto Melloni (ed.), Martin Luther: a Christian between reforms and modernity (I 5I 7-2OI7), Berlin-Boston $2017,1339$. 
not explain whether these 'heretics' included Lutherans or other Protestants, although this may well have been the case. ${ }^{20}$

In 1546 a letter from Francis Xavier requesting the establishment of the Inquisition in Goa noted that Lutheranism was not yet seen as a threat there, 'as there are many who live by Mosaic law and by the Moorish faith, with no fear of God or shame before the world. And since they are many and spread throughout the fortresses, we have need of the Holy Inquisition and many preachers'. ${ }^{21}$ Jews and Muslims were feared most and the key to resolving the problem was seen as an Inquisition, together with missionaries to instruct and effect conversions.

In $155^{2}$ there were signs of alarm about the circulation of Lutheran ideas in Asia. Writing to his brethren in Portugal in December of this year, the General of the Jesuit College in Goa stated that in Hormuz, the Dutch Jesuit Kaspar Berzée, who had been at the College of Jesus in Coimbra in 1546 , had 'captured seven or eight heretics, amongst whom he found many Lutheran and heretical opinions; they rejected purgatory and the Church of Rome and, in some cases, the immortality of the soul'. ${ }^{22}$ Berzée's response, at a time when the use of repressive measures to combat these ideas was intensifying in Portugal, was unusual: 'by arguing with them and admonishing them, he finally managed to convert them and reunite them with the Church'.23 Rather than opting for harsh punishment, he chose to educate through debate and, in his own words, managed to lead those who had strayed back to Catholicism.

Also in December $\mathbf{1 5 5}^{2}$, the priest Belchior Nunes Barreto wrote from Vasai in India that 'I have found some Lutherans here'. ${ }^{24}$ He added that they were foreigners serving as bombardiers in the royal fleet who 'have come here to sow the seeds of heresy, and this is a very dangerous thing in these parts since there is so much loose, dissolute behaviour here'..25 His response was different from that of Berzée. Deploying the language of segregation, he argued that the Crown should be warned 'not to allow the Flemish, English, Germans and French to come here [to India], since we know that many have been in the company of Moors and others

${ }^{20}$ Documentação para a história das missões do Padroado Português do Oriente. India, ed. António da Silva Rego, Lisbon $195^{\circ}-2$, iii. 169. ${ }^{21}$ Ibid. iii. $35^{1 .}$ 22 'recolhidos sete ou oito hereticos, nos quais achou muitas opiniões luteranas e hereticas; negavão o Purgatorio e a Igreja romana, e alguns a imortalidade da alma': ibid. v. $243-4$.

23 'Dizputando com elles e admoestando-os, finalmente os converteo e trouxe a união da Igreja': ibid. 24 'Achei quaa alguns lutheranos': ibid. v. 261-2. ${ }^{25}$ 'tem vindo qua semear suas heregias, e isto he cousa muy perigosa nestas partes, pola muita dissolução e larguesa que ay na terra': ibid. 
THE REFORMATION AND THE PORTUGUESE SEABORNE EMPIRE 289 infected with Lutheran ideas'. ${ }^{26}$ Instead of trying to convince them of the error of their ways, he declared, 'I have arrested them and will send them to the bishop: I do not know how this will end. One was so sly and subtle in spreading his heresies that he may have done great harm.' 27 Juan de Albuquerque and the episcopal authorities continued to provide the support required in Asia to enable heresy to be punished. The alarm, which had been sounded much earlier in Europe, reached India in the years after the establishment of religious boundaries based on the Peace of Augsburg (1555).

In 1560 an Inquisition tribunal was created in Goa, ${ }^{28}$ which was actively supported by the Jesuits into the mid-1570s. ${ }^{29}$ Most of the case files have been lost: they were destroyed when the Goa Inquisition was closed down in the nineteenth century due to pressure from the British authorities. This makes it very difficult to to analyse or reach any clear understanding of how Lutheran ideas circulated. The information which has survived, contained in a directory complied in the seventeenth century by the local Holy Office deputy João Delgado Figueira, records that out of the 3 , 8oo cases heard between 1561 and 1623, 44 per cent concerned 'cristãos da terra' ('Christians of the land', the name given to local converts, baptised after the arrival of the Portuguese in Asia) found guilty of heathenism. 18 per cent of cases concerned Islam and 9 per cent Judaism, whereas only 1.5 per cent were suspected of Lutheranism. $3^{\circ}$ When the Inquisition was founded it applied the same policies in Asia that were used in Portugal against Lutherans, which resulted in few convictions, and those mainly of foreigners.

Between $15^{62}$ and $15^{80}$ a total of twenty-two cases involving 'Lutheranism' was heard by the Goa Inquisition. ${ }^{31}$ Apart from the initial

${ }_{26}$ 'que não deixem vir caa framangos, ingreses, alemães nem franceses porque de muitos sabemos que são lançados com os mouros e outros que são inficionados da secta lutherana': ibid.

27 'fi-los prender e se mandarão ao senhor bispo; não sei em que parara o negocio. Hum era tão delgado e sotil em semear suas heregias, que podera fazer muito mal': ibid.

${ }^{28}$ Cunha, A Inquisição; José Pedro Paiva, 'The Inquisition tribunal in Goa: why and for what purpose?', Journal of Early Modern History xxi (201 7), 565-93.

29 Miguel Rodrigues Lourenço, A articulação da periferia: Macau e a Inquisição de Goa $\left(c .15^{82-c .1650}\right.$ ), Lisbon 2016, 73-8o. According to Rodrigues Lourenço (pp. 88-99), in the mid-1570s Jesuit involvement in the work of the Inquisition was called into question, but would resume from the 158 os onwards.

$3^{\circ}$ Marcocci and Paiva, História, 112.

${ }^{11}$ Data gathered from Reportorio geral de três mil oitocentos processos que sam todos os despachados neste Sacto Officio de Goa e mais partes da India do anno de mil e quinhentos e secenta e hum, que começou o dicto Sancto Officio até o anno de mil e seiscentos e vinte e três com a lista dos inquisidores que tem sido nelle e dos autos públicos d fee que se tem celebrado na dita cidade de Goa, feito pelo licenciado João Delgado Figueyra do Dezembargo de Sua Magestade, promotor e deputado do dito Sancto Officio, Biblioteca Nacional de Portugal, Lisbon, codex 203. 
short-lived panic when eight cases were investigated in $15^{63}$, there are no further traces of large-scale repression (three cases in 1567 , two in 1566 and 1575 and one each in the years $1562,1568,1569,1572,1577$, 1578 and 1580$)$, although the sentences were harsh. Two individuals were handed over to the secular arm to be burned: the first, in $15^{63}$, was the Frenchman Gaspar de Santamen, followed by another French subject, Jean Cointa, in $1572.3^{2}$ In almost all the other cases the defendants abjured and were sentenced to terms of imprisonment and to wear penitential garments for life. In some cases there was the added ignominy of appearing at an auto-da-fé with a rope around the neck. No women were convicted, although many of the accused were married to Portuguese women which suggests that although some of these beliefs may well have been shared by women, the Inquisition was not inclined to pursue them.

Only three of the individuals sentenced were Portuguese. The first was a soldier from Lisbon, Luís Fernandes. In 1568 he was found guilty of 'doubting the liturgy and the veneration of images' and given a six-month prison sentence. 33 He was followed by Francisco Rodrigues, a New Christian from the Algarve, resident in Cranganor, whose trial was concluded at the 1578 auto-da-fé when, having escaped captivity, he was sentenced to be burned in effigy. 34 Finally, in 1580 , Justo Feijó, also from Lisbon, was sentenced at an auto-da-fé to a term of imprisonment and to wear penitential garments, at the discretion of the inquisitors. 35 The others were foreigners (six French, two Dutch, one Englishman, one Armenian, two Germans and seven Flemings), most of whom were bombardiers serving in the Portuguese fleet, from which it may be inferred that certain Lutheran beliefs were known and discussed aboard Portuguese vessels.

The focus on the French is highlighted in information sent by the first Goa inquisitors to the inquisitor-general Henry in December 1562. They reported that they had arrested 'some foreigners, French subjects, as followers of the Lutheran sect and, according to our investigations, this appears to be a common offence amongst these people'. $3^{6}$ They noted that it was 'a very dangerous evil for this land that can be spread by these men, which God does not allow' 37 and in order to prevent this recommended that, in the interests of 'preserving the purity of the faith', the inquisitor-general should arrange for a law to be passed which forbade

\footnotetext{
$3^{2}$ Ibid. fo. $14^{\mathrm{r}-\mathrm{v} \text {. }}$

33 'não sentir bem do culto e veneração das imagens': ibid. fo. 440v.

34 Ibid. fo. 308 r.

35 Ibid. fo. $396 \mathrm{r}$.

$3^{6}$ 'alguns franceses estrangeiros por culpas da secta lutherana, e segundo se vai descobrindo parece este erro geral entre elles': António Baião, A Inquisição de Goa: tentativa de história da sua origem, estabelecimento, evolução e extinção (introdução à correspondência dos inquisidores da India, 1569-1630), Lisbon 1945, 41.

37 'este mal mui perigoso nesta terra e pella via destes homens se poderá semear nella, o que Deos não permita': ibid.
} 
THE REFORMATION AND THE PORTUGUESE SEABORNE EMPIRE 291 'any foreigner from travelling here and that there should be a law to ban foreigners from entering the country on pain of death or exile to the galleys for life, with their assets handed to those who denounce them'..$^{8}$

However, despite such alarms, the persecution of alleged Protestants was never the main focus of the work of the Holy Office in Asia. From the mid157 os onwards greater attention was paid to local Hindus and Muslims, 39 as the inquisitor Bartolomeu da Fonseca peremptorily affirmed in 1576: "the greatest care is taken with local Christians, which is the main concern of this tribunal'.$^{\circ}$

The relatively low level of surveillance of attitudes resulting from the rupture of the Church caused by the ideas of Martin Luther which defined the actions of the Portuguese Inquisition, was also reflected in the stance taken by the diocesan authorities. In fact, analysis of the $15^{68}$ Constitutions of the archdiocese of Goa established by Archbishop Gaspar de Leão $\left(155^{8-67}, 1572-6\right)$ reveals that there are no references to the struggle against Lutheranism in the prologue or in the main text. ${ }^{1}$

\section{What happened in Brazil?}

There are indications that Protestant ideas were circulating in Brazil in $1559 \cdot 4^{2}$ In a letter to the local governor, Tomé de Sousa, dated 5 July, Manuel da Nóbrega, the first Jesuit Provincial in Brazil, sounded the alarm: 'and since there is no sin in existence that cannot be found in this land, I have also encountered Lutheran opinions and those who defend them; since we no longer have to deal with the heathens by using argument to correct their errors, we [now] have heretics to contend with and must defend the Catholic faith'.43 This was due to the presence

$3^{8}$ 'non passar ca nenhum estrangeiro e que se devia fazer lei prohibitiva de sua vinda com pena de morte ou degredo para sempre para as galees e perdimento de bens para quem os acusar': ibid.

39 Giuseppe Marcocci, 'A fé de um império: a Inquisiçāo no mundo português de Quinhentos', Revista de História (University of São Paulo) cliv (2011), 86-7.

$4^{\circ}$ António Baião, A Inquisição de Goa: correspondência dos inquisidores da India (1 560 I63o), Lisbon 1930, 32-4.

$4^{1}$ Constituiçoens do arcebispado de Goa, Lisbon $15^{68 .}$

$4^{2}$ In Mexico, in March 1560 , during the first auto-da-fé held in Spanish America, an Englishman and an Italian were sentenced as 'Lutheran heretics': Magnus Lundberg, Unification and conflict: the church politics of Alonso de Montúfar OP, archbishop of Mexico, I554-I572, Uppsala 2002, 103 .

43 'e porque não há peccado que nesta terra não aja, tambem topei com opinioens luteranas e com quem as defendesse; porque já que não tinhamos que fazer com o gentio em lhe tirar suas erroneas por argumentos tivessemos [agora] hereges com que disputar e defender a fe catholica': Cartas do Brasil e mais escritos do $p$. Manuel da Nóbrega (Opera omnia), ed. Serafim Leite, Coimbra 1955, 327. 
since November 1555 of around five hundred French colonists, some of them soldiers, under the command of Nicolas Durand de Villegagnon, and based at Fort Coligny in Baía de Guanabara, very near to Rio de Janeiro. They were joined in 1557 by another group which included Calvinists from Geneva.44 Relations between the two groups of Frenchmen were not good, causing some to flee to various different locations between Rio de Janeiro and the captaincy of Sāo Vicente. This was the situation that had caused Nóbrega's anxiety, even before the French were defeated and expelled by Portuguese troops commanded by the governor Mem de Sá in March 1560.

As in Asia, it was the Jesuits who sounded the alarm in Brazil. On 22 April 1560 , in Santos, the priest Gonçalo Monteiro, the local ecclesiastical judge delegated by the bishop of Bahia, opened proceedings against Jean Cointa, seigneur de Boulez, one of the Frenchmen who had been based in Fort Coligny in 1555 , from whence he fled, claiming disagreements with the Calvinists. The judge was pressurised into taking action by the Jesuit Luís da Grã, who, together with other members of the Society of Jesus, gave evidence at the trial. Grã knew of Cointa's behaviour in the town of Santos and denounced him because he had told various people, belittling papal potestas, that the Church of Rome was no more honourable than that of Lisbon or Paris, that the pope was 'a man, like any other' and that his bulls were 'a fraud to gain money'. Like Luther, he upheld the principle of sola scriptura, i.e. that 'only the Holy Scriptures were valid', proposed a dual rather than a tertiary afterlife ('there would be no purgatory, only heaven and hell'), believed in sola fide, i.e. that faith was the key to salvation ("the Passion of Christ is sufficient to lead man to heaven'), and considered that all human works were tainted by original sin and worthless in terms of obtaining salvation ('our good works are good through the love of God but we should guard against thinking we will be saved by doing good works, since this is a great sin and will send us to hell'). He also supported the doctrine of universal priesthood and held that 'matrimony is more perfect than religion and God does not forbid priests to marry'. For Grã, there was no doubt that Cointa and some of his other 'companions' who had left Rio de Janeiro with him for the captaincy of Sāo Vicente 'were not firm of faith', and this was the reason why, 'on behalf of the Holy Mother Church and the Holy Inquisition', he implored the ecclesiastical judge of Santos to investigate the case, arrest the Frenchman and deliver him to the Inquisition or to the bishop of Brazil. 45

44 Jean Claude Laborie, 'Le Huguenot au Brésil à travers les documents portugais (1560-1684)', Bulletin de la Société de l’Histoire du Protestantisme Français cxliv (1998), $5^{6} 3-5$.

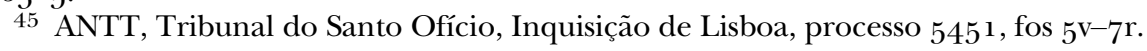


THE REFORMATION AND THE PORTUGUESE SEABORNE EMPIRE 293

The evidence given by Manuel da Nóbrega clearly illustrates the ideas which Cointa was disseminating amongst the Portuguese settlers living on the coast of Brazil between Bahia and Santos. He confirmed that the Frenchman was reading banned books and that they had both discussed the 'heresies of Germany' in conversations in Bahia, sometimes at dinner when the governor of Brazil, Mem de Sá and even the bishop, Pedro Leitão (1558-74), were present. $4^{6}$ In the course of one of these conversations, in Bahia, Cointa spoke very contemptously of Pope Clement VII, whom Nóbrega defended as 'very righteous' and the 'persecutor of Martin Luther'. Discussing Luther was evidently not taboo at the time in Brazil and Portuguese subjects who were above suspicion, such as the Jesuit, the governor and the bishop, spoke of him. On one occasion, reflecting on the 'value of works', Cointa said that he would like to know Calvin's opinion on the subject and was promptly reprimanded, since Nóbrega considered Calvin a 'great heretic'. Books, together with engravings of Luther and scenes from his disputes with the Catholics, were widely used to spread Protestant ideas and attitudes; these also circulated in Brazil.47 The seigneur de Boulez voiced 'many errors about predestination' and had managed to read an extract from Luther which he had copied into a 'notebook that he had'. When Nóbrega reprimanded him for reading Luther, since his works had been banned, he replied that 'in his country it was permitted to read all books'. According to the Jesuit, Cointa 'praised the heretics and said that they were well educated', argued that some words were missing in the Paternoster from the Greek version and that the Books of Maccabees were not authentic. Nóbrega also raised the issue of Luther's wife 'since he had formerly been an Augustinian friar', which he said that he had learned from reading a Catholic book, a point Cointa excused, alleging that the German reformer had only been a religious in his youth. $4^{8}$

Seven other witnesses were heard in addition to Luís da Grã and Manuel Nóbrega. Some provided evidence that justified the Jesuits' greatest fears, given the extent to which the ideas of Cointa and other Frenchmen had spread, making the settlers doubt their faith and even questioning the worth of the Jesuits. According to José Adorno, a member of the Misericórdia of Santos, a brotherhood founded by laymen and clergy under royal protection, when he was talking one day to the priest Luis da Grã in the captaincy of Sāo Vicente, the latter told him that Jean Cointa

$4^{6}$ According to Cointa the bishop kept some of his books but could not understand them because they were written in French: ibid. fo. $34 \mathrm{v}$.

47 The importance of printed books and engravings in transforming the ideas of Luther into a mass movement, in general terms, has also been underlined: Mark U. Edwards, Jr, Printing, propaganda and Martin Luther, Berkeley, CA 1994.

$4^{8}$ ANTT, Tribunal do Santo Ofício, Inquisição de Lisboa, processo $545^{1}$, fos $7 \mathrm{v}-8 \mathrm{r}$. 
was 'a Lutheran', to which he replied that if he was, he had deceived him, since he had thought that he was a good Christian. 49 Cristóvão Dinis, a resident of Santos, testified that when he was in Rio de Janeiro speaking about the French, he had said that they had no crosses and churches in Fort Coligny and that the prayer books that they used 'had no Gloria or images and deserved to be burnt', which Cointa contested, affirming that they were just as Christian and 'virtuous as the Jesuit priests'. $5^{\circ}$

Despite these accusations, on 14 May $15^{60}$ the ecclesiastical judge Gonçalo Monteiro, showing himself to be more open-minded than the Jesuits and perhaps unwilling to commit himself to a decision which he did not have the authority to make, since heresy, by then, usually came under the jurisdiction of the Inquisition, issued an order in which he dismissed these statements, concluding that it does not appear in any way to be an important matter, or one that is binding and I therefore absolve [Jean Cointa] and appeal to His Lordship the Bishop'. ${ }^{5^{1}}$ The files were then sent to Pedro Leitão, bishop of Bahia. Meanwhile, Manuel da Nóbrega took other steps. Writing to the inquisitor-general Henry in April $15^{60}$ to describe the conquest of Fort Coligny, he stated that German heresies were practised there:

chiefly those of Calvin, who is in Geneva, according to information from these people and from their books, which hold him in high regard, and they have come to this land to sow the seeds of heresy amongst the heathen: according to our information, they have ordered many heathen children to learn them from the same Calvin and others so that they may later be masters. $5^{2}$

The concern was now that the indigenous peoples, the main target for Jesuit missionary endeavour in the area, might be influenced by Calvinism.

Echoes of this reached Diego Laynez, the Jesuit General in Rome, via José de Anchieta, who seemed to be suggesting that Jesuits in Brazil had made a collective decision to move onto the offensive. Writing on 1 June from Sāo Vicente, he referred to the 'Calvinists' in Rio and explained that in Piratininga Jean Cointa 'belches out the stench of his errors' concerning the 'images of saints which the Holy Church approves, of the Most Sacred body of Christ ... and many other things'. He touched on a very sensitive point in stating that the Frenchman chose his words well and in such a way that to the common people [his ideas] did not seem bitter at all, but very sweet'. He praised his companion Luís da Grã who was combatting

49 Ibid. fo. $9 \mathrm{v}$.

$5^{\circ}$ Ibid.

$5^{1}$ Ibid. fo. $11 \mathrm{r}$.

$5^{2}$ 'principlamente as de Calvino que esta em Genevra, segundo soube delles mesmos e pollos livros que lhe acharão muytos, e vinhão a esta terra a semear estas heresia pelo gentio e, segundo soube, tinhão mandado muitos meninos do gentio a aprendê-las ao mesmo Calvino e outras partes pera depois serem mestres': Monumenta Brasilae, ed. Serafim Leite, Rome 1958, iii. 244. 
THE REFORMATION AND THE PORTUGUESE SEABORNE EMPIRE 295 'this pestilence' and was prepared to 'root out this evil that had begun to sprout', denouncing the case to the ecclesiastical judge and 'admonishing the people in his sermons to keep away from these men and the books that they had brought, which were full of heresies'. In other words, Grã was fighting Protestant ideas in his sermons, putting these doctrines and his attack on them at heart of contemporary public debate. Finally, Anchieta expressed his fear that the doctrines which Cointa was introducing would bear fruit, since the common people 'marvelled' at him.53

A few months later, on 28 December 1560 , the vicar-general, bailiff and other officials of Bishop Pedro Leitão in Bahia arrested Jean Cointa, although he resisted, declaring that no bishop or archbishop had the legal authority to imprison him.54 Leitão, who had arrived in the diocese approximately one year earlier and would have been keen to eradicate deviance, had studied at the University of Coimbra at the time of the scandal involving certain teachers at the local College of the Arts accused of Lutheranism, who were tried by the Inquisition in $155^{2}$. He would therefore have been aware of this issue.

With the defendant imprisoned in the public jail, since there was no separate ecclesiastical prison at the time, witnesses were heard again, and various Jesuits actively collaborated in the proceedings, corroborating the essential facts which the ecclesiastical judge from Santos had already determined. Baltasar de Góis, for example, stated that the Frenchman 'praised the work of Calvin highly, saying that he was very virtuous and did many charitable deeds and that wherever Calvin went, everything was blessed'.55 João Rodrigues, a friar in the military Order of Avis, testified that he had become a friend of the seigneur de Boulez and that when he was in Pernambuco, he had heard from the governor of Olinda that one day when Cointa was at mass secretly reading a book, the governor asked him what he was doing and he replied that he was reading a 'banned' text in order to 'learn about the habits of the Lutherans' and that because he was educated he had to debate in order to 'fight for the faith' $.5^{6}$ A woman swore that Cointa claimed that 'images were pieces of stone and bread' and that 'it was not God who had created mass, but the

53 'començo a regoldar de su estomago lleno el hedor de sus errores ... imagenes de los santos que aprueva la Santa Iglesia, del Sacratissimo Cuerpo de Christo ... y outras muchas cosas ... de manera que al paladar del pueblo ignorante [as suas ideias] no solamente no parecian amargas, mas aún mui dulces ... arancar las raizes, aun tiernas deste mal que començava a brotar ... en los sermones publicos amonestava al pueblo que se guardasse destos hombres y de los libros que truxeron que eran llenos de herejias': ibid. iii. $264-5$.

54 ANTT, Tribunal do Santo Ofício, Inquisição de Lisboa, processo $545^{1}$, fo. 1 r-v.

55 'louvava muito as obras de Calvino dizendo que era muito virtuoso e fazia muitas esmollas, e homde quer que o dito Calvino estava tudo heram santidades': ibid. fo. 2 r. $5^{6}$ 'pugnar pela fee': ibid. fo. $3^{\mathrm{v}}$. 
clergy, to earn money', and consequently her husband no longer wanted her to attend.57 The Jesuit Adão Fernandes confirmed that in Rio de Janeiro he had heard Cointa affirm that 'the French were better Christians than the priests from the Order of Jesus'.$^{8}$

On 26 June $15^{61}$, when the defendant had been in jail for around six months, the bishop of Bahia ordered new inquiries to be held, this time at the residence of Brás Fragoso, the judge and prosecutor-general of Brazil, which is to say he brought in the secular authorities. Cointa was then questioned for the first time. The intention was to discover why he had come to Brazil and he replied that he had arrived with Villegagnon's fleet but had fled after some 'Calvinists' appeared. Cointa was then asked whether 'he had taught any points of religion or written any statutes' when he was in Fort Coligny, which he denied, but agreed that the Calvinists imposed religious services in the manner prescribed by Calvin, arguing that the body of Christ could be consecrated in any piece of leavened bread, that water should not be added to the wine when it was consecrated as the blood of Christ, and that it was not necessary to use oils in baptisms. In response to further questions from the bishop based on statements given by witnesses, he denied almost everything that he was accused of, hesitating only when asked whether there should be images of saints in churches, as in Rome. To this he replied that in AD 32 'there were no such images in churches and it was Pope Martin who first ordered them to be painted on the doors of the churches of St Peter', which led to great 'controversy'.59

Less than a month after this first interrogation, Leitão ordered that new witnesses should be heard. This time, almost all of them were prisoners in the same jail as Cointa who had regularly conversed with him on matters of faith. Although sometimes only vaguely understood, these subjects were not beyond the reach of ordinary people, including criminals. Lutheranand Calvinist-inspired beliefs and attitudes were thus being openly discussed in a prison in Brazil.

Duarte de Meneses noted that the Frenchman affirmed that there should be no pope in the diocese of Rome, because it was 'just monkey tricks, since after St Peter had served as pope, God would not allow any other, and that popes nowadays wanted money and that was why they became popes', that souls could not be saved with money, masses and other prayers, and that 'only the text of the Bible should be believed' and not the councils of the popes. In addition, he rejected various

\footnotetext{
57 'imagens heram um pedaço de pedra e pao ... misa não a fizera Deus senão os cleriguos per ganharem dinheiro': ibid.

$5^{8}$ 'os franceses eram melho res cristãos que os padres da Ordem de Jesus': ibid. fo. $4^{\mathrm{v}}$.

59 'não havia tais imagens nas igrejas e foi o papa Martinho I que mandou pintar as primeiras nos portais das igrejas de S. Pedro': ibid. fos $22 \mathrm{r}-25^{\mathrm{v}}$.
} 
THE REFORMATION AND THE PORTUGUESE SEABORNE EMPIRE 297 Catholic beliefs: the veneration of images, purgatory, the value of confessions made to clergymen (claiming this should only take place between the believer and God), the religious life, the authority of the bishops, the legitimacy of excommunication and fasting. He argued that priests should be able to marry, preachers should be laymen, and that after the consecration of the Holy Sacrament, one should not take the host, as was the practice in churches in Brazil, but 'each person should be given a small piece of bread and portion of wine to drink, as the Lutherans did'. ${ }^{60}$ Many of the points that had led to the split within Christianity were subjects for conversation and reflection.

Sometimes there were even debates, with arguments, and the jailer joined in and presumably was able to transmit these ideas beyond the confines of the prison. The jailer testified that he had asked Jean Cointa why he thought that there should be no popes in Rome and received the reply that 'this is not written in the Holy Scriptures', to which he responded by informing him of the views of the preachers whom he had heard on this subject. ${ }^{61}$ In short, the jail became a place for spreading the beliefs of Jean Cointa, including his evident praise for 'John Calvin, who had written many books, was highly educated and a close friend of God and who preached the Gospel miraculously', for 'Martin Luther [who] was very virtuous and educated and a friend of God', and the fact that they had together 'converted all of Italy and Germany', according to a statement given by another witness. ${ }^{62}$

The famous case of William Gardiner in $\mathbf{1 5 5 2}$ at the Royal Chapel in Lisbon also featured in these discussions, since Cointa introduced him as an example of a martyr who, deliberately and out of faith, had defied the authorities of the Crown and the Catholic Church: 'the Lutheran [William Gardiner] who seized the Holy Sacrament from the hands of the priest who was celebrating Mass before the king [John III] and was burnt alive for this in Lisbon, was a great man inspired by great Lutheran scholars, who knew when he undertook the said act that he would die for this, but would die for the truth'. ${ }^{63}$ Even the Inquisition

\footnotetext{
6 o 'bugiaria avelo, porque depois que São Pedro fora papa Deus não permitira que ouvesse mais outro papa e que os papas que agora avia levavam dinheiro e que era pera isso que eram papas ... so se devia dar credito as Escrituras da Brivia ... dando a cada hum hum pequeno de pão e porção de vinho para beber sobre elle como fazião os luteranos': ibid. fos $11 \mathrm{r}-12 \mathrm{v}$.

61 'isso não estava escito nas Escrituras': ibid. fos $13^{\mathrm{v}-1} 5^{\mathrm{r}}$.

62 'João Calvino, que fizera muitos livros, que era muito grande leterado e muito amigo de Deus e que pregava o Avangelho milagrosamente», de «Martim Lutero [que] era muito virtuoso e grande leterado e amigo de Deus ... Martim Lutero [que] era muito virtuoso e grande leterado e amigo de Deus': ibid. fos $15^{\mathrm{v}-1} \mathbf{7 r}$.

63 'o Lutaro [William Gardiner] que tomou o Santo Sacramento com as mãos do sacerdote que estava celebrando missa diante del rey que Deus tem [D. João III], o
} 
was discussed, and criticised by Cointa who said that he would rather they 'burnt' him than 'made him stand at the hour for mass at the doors of the cathedral holding a torch'. ${ }^{6}$

On 3 August ${ }_{15}^{61}$ Leitão began a new interrogation of the defendant, this time in the presence of the chief judge ('ouvidor geral'), Brás Fragoso. The prelate asked Cointa if he held beliefs 'contrary to the religion of Our Lord, his holy commandments or the Church of Rome' and ascertained that he knew the commandments of the Church, the Ten Commandments, the seven deadly sins, the Paternoster and Hail Mary, and the sign of the cross, but not the Hail Holy Queen. Cointa confirmed that he had spoken about Lutherans, Jews and Moors in many places, but 'did not believe in the opinions of the Lutherans or those of Calvin'. ${ }_{5}$ The conclusion, dated 25 August and written in Leitão's hand, stated that 'Given the material they contain, I refer these files to the President and Deputies of the Holy Inquisition in Lisbon and hereby order the said Monsier de Bolles to be delivered to the master of the ship Santiago which is sailing to the kingdom, so that he may deliver Monsier de Bolles to the said inquisitors, together with these files' ${ }^{66}$

Jean Cointa was not the only victim of episcopal surveillance. According to evidence given by the Jesuit Leonardo do Vale (who was commissioned by Luis da Grã to write to his brethren in the church of São Roque in Lisbon in June 1562), the French had also been spreading heretical ideas in Paraíba. The hand of justice had also arrived there in the form of Pedro Leitão, with the support of the Jesuits, to instruct those who were convicted in how to become good Catholics. The bishop ordered the arrest of two residents who were tried in his tribunal. One was sentenced 'to solemn penance at the cathedral and the other to wear the sanbenito for life and attend the [Bahia] College twice a day and also forbidden to travel outside the city walls'. Leitão ended on a note which suggested that in extreme cases he would apply the most severe penalties: 'Monsieur de Bolles is not to be burnt, as he is being referred to the cardinal. ${ }^{67}$

qual queimarão por yso na cidade de Lisboa, hera homem pera muito e mandado pelos grandes leterados luteranos, e que, quando fora a fazer o sobredito, que bem sabia que o avião de matar por yso, mas que fora a morrer pela verdade': ibid. fo. 13 r.

64 'o porem hua ora a missa ha porta da See com huma tocha na mão': ibid. fo. $16 \mathrm{v}$.

65 'contra a fé de Nosso Senhor, contra os seus santos mandamentos ou contra a Igreja de Roma ... não cria nas opinioes dos luteros nem de Calvino': ibid. fos 26r-27r.

66 'Remeto estes autos visto a materia delles aos senhores presidente e deputados da Sancta Inquisição de Lisboa, e mando que o dito Monsier de Bolles seja entregue ao mestre da nao Santiago que ora vai pera o Reino, pera que elle entregue o dito monsier de Bolles aos ditos senhores enquisidores com estes autos': ibid. fo. $27 \mathrm{v}$.

${ }_{7}$ 'com huma penitencia solene na See e outro com hum sambenito para sempre e que não saisse fora dos muros e visitasse este Collegio [da Baía] duas vezes cada dia ... o Monsier de Bolles deixa de ser queimado por estar remetido ao cardeal': Monumenta Brasilae, iii. 498 . 
However, for reasons that cannot be determined, neither Cointa nor the case file reached the Lisbon Inquisition in accordance with Pedro Leitão's decision. On 9 January 1563 , citing the Cum audiamus, a papal brief which gave the inquisitor-general jurisdiction over any acts of heresy that were being tried in the episcopal tribunals, ${ }^{68}$ Henry ordered that the prisoner should be handed over to the Inquisition and that a copy of the brief should be filed in the diocesan notary office to ensure that 'in future, similar cases would be dealt with in the same way'. ${ }^{69}$ Having received this notification in Bahia in March, the bishop gave new orders to his vicargeneral: Boulez was to be delivered to the Inquisition, where he was imprisoned on 28 October $15^{63} .7^{\circ}$ He was eventually sentenced to abjure his errors de formali at a private auto-da-fé on 12 August 1564 and sentenced to a term of imprisonment at the discretion of the inquisitors, to do spiritual penance, including the obligation to receive communion three times a year, and was banned from leaving Portugal without permission from the inquisitors. ${ }^{71}$ This punishment did not last long, since on 15 November, having been detained in the San Domingos convent and been given a positive recommendation by his Dominican confessor, he was released by Henry. ${ }^{2}$

On an unknown date, Cointa set sail for Goa, where he was once again arrested by the local Inquisition. In his first trial, in 1569 , he was sentenced to abjure de vehementi; 73 later, in his second trial, he was given the maximum sentence. Although he had escaped death in Brazil, he was now handed over to the secular authorities and burned at the stake in 1572 , together with Captain Jerónimo Teixeira de Macedo, a Portuguese subject who had also attempted to convert others while they were both prisoners in Goa.74 As in Brazil, the prisons in Goa seem to have been places where heresy was promoted.

Many years later, Pedro de Vila Nova was also punished for the Lutheran beliefs that he had temporarily adopted. During the first Inquisition

68 On this brief and its importance see Giuseppe Marcocci, I custodi dell'ortodossia: Inquisizione e Chiesa anel Portogallo del Cinquecento, Rome 2004, 98-9, 164-75. See also José Pedro Paiva, Baluartes da fé e da disciplina: o enlace entre a Inquisition e os bispos em Portugal (I536-I750), Coimbra 201 1, 386-93. Recently Juliana Torres Pereira referred to this episode but disregarded certain important facts: 'Um arcebispo em defesa do poder episcopal: as relações entre D. Frei Bartolomeu dos Mártires e o Santo Ofício Português (1559-1582)', unpubl. PhD diss. Sao Paulo 2017, 14-16.

69 ANTT, Tribunal do Santo Ofício, Inquisição de Lisboa, processo $545^{1}$, fo. $3^{\text {ov. }}$

$7^{\circ}$ Ibid. fos 3or, $31 \mathrm{v}$. $7^{1}$ Ibid. fos $67 \mathrm{v}-68 \mathrm{v}$. $7^{2}$ Ibid. fo. $68 \mathrm{v}$.

73 Reportorio geral de três mil oitocentos processos, codex 203, fo. 483 .

74 Israel-Salvador Révah, 'Jean Cointa, sieur des Boulez exécuté par l'Inquisition de Goa en 1572', Istituto Universitario Orientale: Annali: Sezione Romanza ii (1960), 71-5; Marcocci and Paiva, História (2nd edn), 116; ANTT, Tribunal do Santo Ofício, Conselho Geral do Santo Ofício, livro 94, fos $129^{\mathrm{r}-1} 34 \mathrm{v}$; Reportorio geral de três mil oitocentos processos, codex 203 , fo. $484 \mathrm{v}$. 
visitation in Brazil, in a session held on ${ }_{15}$ January ${ }_{1592}$, Heitor Furtado de Mendonça, having received a denunciation from Luis da Grã, summoned Pedro de Vila Nova. He had been a servant of Jean Cointa and had been with him in Fort Coligny approximately thirty-two years earlier, when he would have been around twenty. There, according to his testimony, when the Genevan Calvinists arrived they 'began to distribute their Lutheran books and sow the seeds of the Lutheran doctrine, opening Lutheran schools for the public and pressuring and forcing the boys and young men to attend them on pain of a whipping'. This was where Vila Nova had learned some of their ideas, which he still remembered, despite stating that he was a Catholic. These included the beliefs that 'God was not present in the consecrated host during mass', the true sacrament was 'receiving a piece of bread to commemorate the body of Christ', neither crosses nor images should be venerated and that there should be 'no celebration of Our Lady'. He also stated that when he and other French subjects escaped from the French fortress in Baía de Guanabara and headed for Sāo Vicente, he had spoken about these matters with some 'negroes' with whom he lived after his escape. In Sāo Vicente he stated that at the time, approximately thirty years earlier, the justice authorities had already questioned him, but he did not specify who they were. He was eventually sentenced to spiritual penance at an auto-da-fé held in Bahia Cathedral in December 1592, at the end of a trial overseen by the inquisitor Furtado de Mendonça, Bishop António Barreiros and other clerics, including the Jesuit Fernão Cardim. 75

There were also unsubstantiated reports that another French subject, Jacques Le Balleur, from the group of Genevan Calvinists, was burned at the stake in Rio de Janeiro in $15^{67}$, an event in which the Jesuit José de Anchieta had played an active role. $7^{6}$

This information was presented very vaguely in 1897 by Arthur Heulhard in a short passage in which he used Pero Rodrigues's early seventeenthcentury Vida do Padre Anchieta as his source. This supposedly stated that, as the executioner had failed to deliver the fatal blow, the Jesuit himself had done so, saying, 'voilà comme il faut le faire'.77 However, given its

\footnotetext{
75 'espalhar seus livros luteranos e a semear sua doutrina luterana, fazendo escolas publicas de sua seita luterana, constrangendo e forçando com açoutes todos os moços e mancebos de pouca idade que fossem as ditas escolas ... Deus não estava na ostia consagrada durante a missa ... receber uma fatia de pão em comemoração do corpo de Christo': ANTT, Tribunal do Santo Ofício, Inquisition de Lisboa, processo 2526 .

${ }_{76}^{6}$ See, for example, Franklin Ferreira, A presença dos reformados franceses no Brasil colonial, $1_{5}$, < http// www.monergismo.com/textos/historia/presenca_reformadires_franceses.pdf $>$, consulted 18 August 2017, and Laborie, 'Le Huguenot', 584-5.

77 Arthur Heulhard, Villegagnon roi d'Amérique: un home de mer au XVIe siècle (I $5 \mathrm{IO}^{\mathrm{O}}$ I572), Paris 1897,171 .
} 

date, this text was a second-hand source, and in fact the priest Pero Rodrigues, the seventh Provincial of the Society of Jesus in Brazil, only refers to the execution of a 'very obstinate heretic' who had been captured in the company of French soldiers and convicted in Rio de Janeiro, adding that Anchieta would have given the instructions to the executioner. He does not state that the convict was Jacques le Balleur. ${ }^{8}$ Basically, Heulhard was reprising themes that had been the subject of heated debate in France in $15^{61}$ concerning the so-called France Antarctique and the martyrs who established the Huguenot presence in Brazil, and in which the works of Jean de Léry and Jean Crespin were key references.79 Crespin's book was rediscovered by Lusophone scholarship at the beginning of the twentieth century via a Portuguese translation of the work by Domingos Ribeiro and had also influenced the book written by the Protestant pastor Álvaro Reis. ${ }^{80}$

As Luís Tavares has clearly shown, Álvaro Reis was more concerned with writing a 'proselytising polemic' and smearing the pious reputation of the Jesuits than with producing a rigorous, well-documented historical analysis. Hence, he portrayed a Jacques le Balleur who, having been spared the death sentence by Villegagnon, would end up being burned at the stake in Rio de Janeiro. However, this inference is highly questionable, since the Genevan would have been hanged rather than burned (a sentence reserved for heretics) by the secular authorities, due to issues concerning military jurisdiction, not by the Inquisition or the episcopal authorities. ${ }^{81}$ Nevertheless, it should be acknowledged that Anchieta may have delivered the said 'comfort' to this or some other convict awaiting death, as described in the Vidas, although there are no other known references in the primary sources that would provide unequivocal proof of this, or in the abundant Jesuit correspondence or Inquisition documents.

$7^{8}$ Pero Rodrigues, Vida do Padre Joseph de Anchieta da Companhia de Jesu, quinto provincial que foy da mesma Companhia no Estado do Brasil (manuscript copy), Pontificia Universitá Gregoriana, APUG 1067. This passage can be found at bk II, chapter vi.

79 Jean de Léry, Histoire d'un voyage fait en la terre du Brésil, dite Amerique, La Rochelle 1578; Jean Crespin, 'Histoire des choses memorables advenues em la terre du Brésil, partie de l'Amerique Australe, sous le gouvernement de N. de Villeg: depuis l'an 1555 jusques à l'an 1558', in Paul Gaffarel, Le Brésil Français au seizième siècle, Paris 1878. On the impact of these disputes in fuelling the religious wars in France see Olga Okouneva, 'La France antarctique au Brésil: le prologue des guerres de religion en France?', PROSLOGION: Studies in Medieval and Early Modern Social History and Culture i (2016), 293-314.

${ }^{80}$ Jean Crespin, A tragédia de Guanabara ou História dos protomartyres do Christianismo no Brasil, trans. Domingos Ribeiro, Rio de Janeiro 1917; Álvaro Reis, O martyr Le Balleur ( 1567 ), Rio de Janeiro 1917.

${ }^{81}$ Luís Fabiano de Freitas Tavares, 'Da Guanabara ao Sena: relatos e cartas sobre a França Antártica nas guerras de religião', unpubl. MA diss. Rio de Janeiro 2016, 57-8. 
This study confirms the lucid conclusions of Giuseppe Marcocci, who has argued, with reference to Portugal, that the country had ready access to Protestant materials and adherents to its doctrines. ${ }^{82}$ The same can be said for its Asian and American territories. Even though the Portuguese inquisitors focused their attentions on European foreigners from beyond the Pyrenees, the ideas, books and reports associated with this complex and extremely malleable world of beliefs and controversies still reached and caused anxiety among those Portuguese who were living in the socalled State of India (a huge territory extending from the east coast of Africa to Macau and Timor) and in Brazil.

In these areas of the Portuguese overseas empire, indications of the presence of people and books associated with Luther, Calvin and other reformers appeared later than in Portugal: in 1539 in Asia, and in 1559 in Brazil. Even so, there was a certain chronological correspondence between the two worlds, given that the first convictions by the Inquisition took place at the beginning of the $15^{60 s}$. In other words, in these parts of the empire persecution intensified in the 1560 . This was precisely the time when repression of these movements reached its peak in Portugal, as fears of their influence grew when cases such as those involving William Gardiner and friar Valentim da Luz came to light. Nor can it be ignored that the warnings came from people and institutions who originated in Portugal. Moreover, following the pattern established in Portugal, women in the empire were rarely involved in convictions for Lutheranism. This discrimination by gender spared them from punishment, possibly because they were not considered intellectually capable of becoming involved in theological disputes. Of course, there were very few white women in those territories.

The similarities between Asia and Brazil do not end there. It is also essential to highlight the very active involvement of the Jesuits. Moreover, despite that fact that the Inquisition had been operational since 1536 , the Jesuits initially looked to the already active episcopal structures and the jurisdiction of the bishops for support in persecuting and punishing those who adopted reformist ideas. It was only from the 1560 on onwards that the Inquisition began to intervene and to dominate in the repression of reform in the empire.

The configurations of the Portuguese empire favoured the emergence of strikingly interconnected histories, linking and facilitating the circulation of material assets, behaviour, beliefs, skills, knowledge and people. The story of Jean Cointa is a prime example of this. After leaving France, he roamed around Brazil, was convicted by the Inquisition in Portugal and travelled to Goa, where he was eventually burned at the stake for the

82 Marcocci, 'Una tierra'. 
THE REFORMATION AND THE PORTUGUESE SEABORNE EMPIRE 303 ideas that he had left behind in all these places. If the ideas of Luther and Calvin managed to reach Asia and Brazil this was, in part, due to figures like him and to the fact that the Portuguese, who had assumed the role of messengers spreading the word of Christ and adherence to Roman Catholicism, had established themselves there.

The available data suggests that the key figures involved in spreading reformist ideas in Asia and America were not Portuguese. Paradoxically, however, and without intending to do so, by opening up routes to these places, they functioned, objectively speaking, as facilitators for other ways of interpreting Christianity, creating the conditions to ensure that the ideas that Luther had outlined from $15^{13}$ onwards could take a global path. 